\title{
Development of Type Drum Kiln to Make Charcoal and Wood Vinegar for The Utilization of Coconut Shell Waste
}

\author{
Yazid Ismi Intara ${ }^{*}$, Budiyanto ${ }^{1}$, Zulbahrum Caniago $^{2}$ and Revando Aldo ${ }^{1}$ \\ ${ }^{1}$ Department of Agricultural Technology, Faculty of Agriculture, University of Bengkulu \\ ${ }^{2}$ Department of Physics, Faculty of mathematics and Natural Science, University of Bengkulu \\ ${ }^{*}$ Corresponding author. Email: yazidintara@unib.ac.id
}

\begin{abstract}
Many coastal communities have not yet developed the potential for processing coconut shell waste and wood cutting industry waste. Making appropriate technology that can provide solutions to problem-solving while utilizing the local potential of the region is a breakthrough that can build the people's economy. The design and development of appropriate technology made in this study is a kiln maker of charcoal and wood vinegar that will be very useful and simple and easy to move. The purpose of this research is the development of a design of appropriate technology for the manufacture of charcoal and wood vinegar which is economical. Test kiln performed using performance testing parameters on each unit used are the operating capacity of the tool, the temperature of combustion that occurs, the time of the final product manufacturing process, the yield of combustion materials, the resulting quality and the calculation of the cost of production. The results show that the tools built have shown the performance of charcoal and liquid smoke makers which are good for application in rural communities. This kiln tool can operate as a charcoal maker or liquid smoke maker or both. In the making of charcoal (without the process of liquid smoke) obtained the optimal charcoal capacity at $10 \mathrm{~kg}$ of small size shell, the combustion temperature runs $150{ }^{\circ} \mathrm{C}$ with a time of 2 hours and a yield of $24.5 \%$. Making liquid smoke (without making charcoal) shows the capacity of fumigation material (shell) using $20 \mathrm{~kg}$, the combustion temperature runs $120^{\circ} \mathrm{C}$ with a time of 6 hours and a yield of $5.5 \%$ or 1.1 liters. Whereas to get the combustion at the same time the liquid smoke obtained the results of the charcoal capacity to produce more than $10 \mathrm{~kg}$ of small size shell, the combustion temperature runs $120^{\circ} \mathrm{C}$ with 2.5 hours with the yield of charcoal and liquid smoke yield of $10.5 \%$ and $1.2 \%$. The results of the analysis of the cost of production with the use of raw materials including coconut shell $10 \mathrm{~kg}$ for making charcoal and liquid smoke are Rp. 2.72 / g, and Rp. 5.65 / ml.
\end{abstract}

Keywords: Appropriate technology, charcoal, coconut shell, kiln, profit analysis, wood vinegar

\section{INTRODUCTION}

Indonesia as a tropical country has abundant natural resources such as coconuts (Cocos nucifera), whose utilization is still very open to further study and development to be optimally utilized. This is also considering that although almost all parts of the coconut have been taken advantage of, many of them are wasted into garbage such as the fibers and shells.

Coconut shells are abundant waste in Bengkulu Province because has a long coastline and is covered with coconut trees along the coast. The utilization of coconut fruit waste through an appropriate technology process will produce many benefits.

The use of appropriate technology is a tool for the welfare of society by prioritizing groups whose capabilities will be enhanced through the use of appropriate technology to improve the quality of business work through assistance so that appropriate technology becomes more optimal [1].

Indicators of appropriate technology are the existence of a conversion of natural resources, absorbed labor, triggered home industries, and increasing community income [2]. Appropriate technology in the development of 
Green Engineering or Green Productivity has four general objectives in order to improve environmental quality and production economy when implemented on the production floor, namely waste reduction, material management, pollution prevention and increase in product value (product enhancement) [3].

Traditionally, the use of coconut products is for fresh consumption, made of copra or coconut oil. Along with market developments and technological support, the demand for various coconut derivative products is increasing, such as in the form of desiccated coconut, coir fiber, shell charcoal, and activated charcoal.

Charcoal (carbonization) is the process of converting an organic substance into carbon or carboncontaining residues in the manufacture of carbonated charcoal [4]. Charcoal is done by burning the material to be charred to remove water content and other materials that are not needed by charcoal, such as hydrogen and oxygen or evaporating material [5].

The charcoal process at high temperatures is called pyrolysis, the tool development for the charring process (this research) is called a kiln. The drum-type kiln design uses drums without gauze and uses coconut shell as raw material for charcoal. The results of the charcoal process using a kiln generally produce a large yield of charcoal with good quality charcoal. Development design of kiln is in addition to being used as to produce charcoal, this appropriate technology can also be used to produce wood vinegar from the smoke produced.

Smoke is the result of incomplete combustion, namely combustion with limited oxygen. Combustion with sufficient oxygen, the result is water vapor, carbonaceous acid gas and ash. In this condition there is no smoke. Combustion with a little oxygen, the resulting smoke consists of carbonic acid gas, alcohol and other organic acids [6].

Wood vinegar is a mixture of a solution and a colloidal of wood smoke vapor in water obtained from wood pyrolysis [7]. One of the benefits of wood vinegar is organic preservative as formaldehyde, so that in addition to reducing the negative impact on the environment $[8,9]$, the utilization of charcoal production into liquid smoke (wood vinegar) is also able to increase the use value of the byproduct [10].

The appropriate technology developed in this study is focused on the coconut shell home industry. This research aims to develop a appropriate technology (kiln: biomass burning tool) that can produce both charcoal and wood vinegar which is economical for the community.

\section{MATERIALS AND METHODS}

The research was conducted in May-June 2020, at the Agricultural Industrial Technology Laboratory, Faculty of Agriculture, Bengkulu University. The equipment used in the kiln performance test was rod type $\mathrm{K}$ thermocouple for the room temperature of the coking, anemometer, infrared thermometer, and 5 gauzes with a diameter of 10 $\mathrm{cm}$. The equipment used in material testing is a scale, aluminum plates, ceramic cups, ovens, and kilns. The material used in this research is the coconut shell.

The research design is to see the performance of the designed tool, then use a graph of the relationship between temperature and time generated in testing the manufacture of liquid smoke. The treatment was carried out four times with each treatment using a performance time of 60 minutes, every 10 minutes for each repetition the temperature was measured using a type k thermocouple. For the charcoal quality, research design used to facilitate the analysis of the description of tool performance on product quality is the treatment of material sizes, namely $1.3-5 \mathrm{~cm}$ (L1), 2. 5-8 cm (L2), and 3.8-13 cm (L3). materials namely $10 \mathrm{~kg}$ and $15 \mathrm{~kg}$. Each treatment was repeated 3 times, resulting in 18 experimental units. Testing the quality of the charcoal produced includes parameters of moisture content, ash content, flight substance content, and bound carbon content. The parameter data from the study will be displayed descriptively on the measurement results in the form of a time-functional graph.

Analysis of cost production folows: the cost of production is all direct and indirect costs incurred by the industry for the production process so that the goods or services can be sold. The formula used to analyze the cost of production is:

$$
\begin{aligned}
& \text { Cost production }=\frac{(A+B)}{J K T} \times C \\
& \mathrm{~A}=\frac{P-N A}{\text { The percentage of tools age }}
\end{aligned}
$$

$$
\begin{aligned}
\text { Explanation: } \mathrm{A}= & \text { fixed cost } \\
\mathrm{B} & =\text { variabel cost } \\
\mathrm{C} & =\text { Percentage } \\
\mathrm{P} & =\text { price of the kiln } \\
\mathrm{NA} & =\text { The last percentage }
\end{aligned}
$$

\section{RESULTS AND DISCUSSION}

\subsection{Design of Charcoal Kiln Equipment}

The making of a charcoal kiln tool is designed with design principles to become an appropriate tool or technology. This tool is one of a series of multipurpose combustion apparatus installation designs using the combustion chamber material from the drum. The design of this charring kiln is a drum-type kiln. The design of industrial tools is carried out based on the use of the charred material that has not achieved the desired results. Therefore, performance testing is carried out which aims to improve the quality of the charcoal results by means of the kiln in order to obtain better results according to the desired quality of charcoal. In this design, an addition was made to the kiln in the form of an airflow equalizer. The equalizer gauze 
provides oxygen reserves which can help to equalize the charring process that takes place in the charring room. The gauze used is arranged to form a pentagon with one equalizer placed in the middle of the charring room. The leveling screen in the middle of the charring room functions as a place for the flow of air entering from the core air hole because the core air hole is in the middle of the auditory space so that it increases the firing rate. heat more evenly throughout the charcoal chamber. The added equalizer gauze is made of wire material with a mesh size of $5 \mathrm{~mm}$ so that the charred material cannot enter the leveling screen. The choice of wire material is because it is easy to find on the market and its thermal conductivity is good enough to spread heat. In the operating procedure, floor design is also carried out from $10 \mathrm{~mm}$ wire mesh so that the charred material does not fall along with the ash when it is burned.

\subsection{Addition Design Kiln for wood vinegar}

Overall, the condenser design results consist of the connecting pipe, the condenser inlet pipe, the condenser body, the condenser outlet pipe, and the support legs. The description of the functions of the chart sections is described in Table 1.

The functional design resulted from considerations, namely the main function of the chimney cone as a gathering place for the chimney output smoke, the function of the connecting pipe as the smoke flow path from the kiln chimney to the condenser inlet pipe.

The condenser as a form of the caster of the condensing medium must have a solid shape so that a supporting part of the condenser body is needed, namely in the form of a support leg that can be assembled. Intended for use on a household scale, this condenser is designed with a practical capacity and shape and is also assemblable so that it can be cleaned of tar and residue that can inhibit the flow of smoke.

Condenser performance tests on the amount of oil produced were carried out 3 times with different levels of average decomposition temperature, namely $178.3{ }^{\circ} \mathrm{C}$, $284.83{ }^{\circ} \mathrm{C}$ and $150.48{ }^{\circ} \mathrm{C}$. Gas, liquid and also solids (charcoal) are products of the pyrolysis process, but the amount of each of these products can be controlled through the process temperature and also the retention time. In the pyrolysis process, a drying process will occur, namely the evaporation of moisture content and devolatilation, namely the volatile matter that comes out of the pyrolysis product material in the form of charcoal in solid form, tar in the form of liquid and gas.

Testing the condenser carried out obtained results with $10 \mathrm{~kg}$ of coconut shell fuel in small, medium, and large materials (whole) for 60 minutes. The best results were found in the first test with small raw materials, with an average temperature of $178.3{ }^{\circ} \mathrm{C}$, the highest temperature reaching $256.7^{\circ} \mathrm{C}$, resulting in a yield of $2100 \mathrm{~g}$ of charcoal and $150 \mathrm{ml}$ of condensate. Then in the second test with moderate raw materials, an average temperature of 284.83 ${ }^{\circ} \mathrm{C}$ was obtained, the highest temperature reached $410.5^{\circ} \mathrm{C}$, resulting in a yield of $2362 \mathrm{~g}$ of charcoal and $80 \mathrm{ml}$ of condensate. Furthermore, the third test with large (whole) raw materials obtained an average temperature of 150.48 ${ }^{\circ} \mathrm{C}$, the highest temperature of $194.6{ }^{\circ} \mathrm{C}$ resulting in a yield of $2451 \mathrm{~g}$ of charcoal and $80 \mathrm{ml}$ of condensate.

Table 1. The condenser parts and their respective functions

\begin{tabular}{|l|l|l|}
\hline No & Part of name & Function \\
\hline 1 & Chimney cone & $\begin{array}{l}\text { the cone space of the } \\
\text { accumulation of chimney exhaust } \\
\text { before being channeled into the } \\
\text { connecting pipe }\end{array}$ \\
\hline 2 & Connecting pipe & $\begin{array}{l}\text { The smoke flow pipeline from the } \\
\text { kiln chimney to the condenser } \\
\text { inlet pipe }\end{array}$ \\
\hline 3 & Condenser inlet & $\begin{array}{l}\text { he smoke intake pipe from the } \\
\text { connecting pipe to be condensed }\end{array}$ \\
\hline 5 & $\begin{array}{l}\text { Outlet } \\
\text { condensor }\end{array}$ & $\begin{array}{l}\text { condensation pipe which lowers } \\
\text { the temperature of the smoke so } \\
\text { that it changes its form from gas } \\
\text { to liquid }\end{array}$ \\
\hline 6 & $\begin{array}{l}\text { The smoke outlet that has passed } \\
\text { through the condensation process } \\
\text { will then accommodate the } \\
\text { condensate in the beaker glass }\end{array}$ \\
\hline
\end{tabular}

\subsection{Working conditions of the Charcoal Kiln}

The performance test of the kiln developed in the Agricultural Industry Technology using coconut shell material was carried out 3 times, the material used in this kiln performance test had a capacity of $10 \mathrm{~kg}$, and $15 \mathrm{~kg}$, each material was tested with the addition of 5 equalizer gauze. The performance test using 5 equalizer gauze for each treatment can be seen in the results in Table 2.

Table 2. Test results of the charcoal Kiln

\begin{tabular}{|l|c|c|}
\hline \multicolumn{1}{|c|}{ Parameters } & $\mathbf{1 0 ~} \mathbf{~ k g}$ & $\mathbf{1 5} \mathbf{~ k g}$ \\
\hline $\begin{array}{l}\text { The Highest } \\
\text { Temperature }\left({ }^{0} \mathrm{C}\right)\end{array}$ & 394 & 367 \\
\hline $\begin{array}{l}\text { The Average } \\
\text { temperature }\left({ }^{0} \mathrm{C}\right)\end{array}$ & 268 & 239 \\
\hline The Charcoal mass $(\mathrm{kg})$ & 2,67 & 3,312 \\
\hline The Percentage $(\%)$ & 26,7 & 22,08 \\
\hline
\end{tabular}

The charcoal processes temperature fluctuates, i.e. the temperature rises in the early minutes, then decrease and rises again at the time of the next coking process. The highest coking temperature was indicated at a capacity of $10 \mathrm{~kg}$. The temperature of each treatment can be seen in Figure 1. 


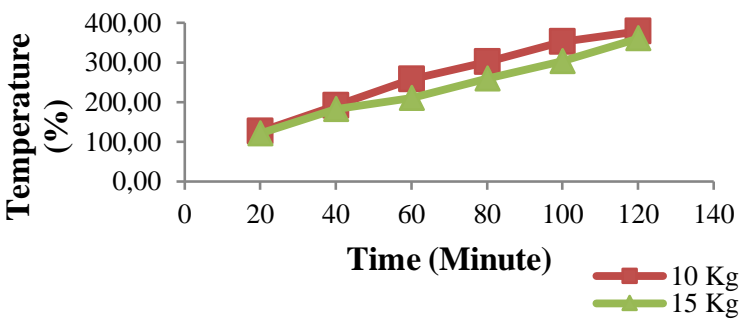

Figure 1. Effect of time on curing temperature

The proper cooking temperature performance in the kiln shows a graph that increases with the addition of time in the $10 \mathrm{~kg}$ capacity treatment from $126^{\circ} \mathrm{C}$ at the beginning of measurement to reaching $378^{\circ} \mathrm{C}$ at the end of combustion. Tests using $10 \mathrm{~kg}$ capacity material obtained the maximum temperature achievement of the charcoal process increased to $378^{\circ} \mathrm{C}$ with a relatively faster temperature rise compared to tests using $15 \mathrm{~kg}$ material. The more reserve air volume in the test using $10 \mathrm{~kg}$ material causes the temperature in the initial process of combustion of the material to be higher so that the increase in the coking room temperature in the test using $10 \mathrm{~kg}$ can be faster than the test using $15 \mathrm{~kg}$ material.

\subsection{Characterization of charcoal products}

The variables observed were moisture content, ash content, volatile matters, carbon content (fix carbon), and yield.

\section{a. Water content}

Testing the moisture content of charcoal can be used to calculate the parameters of charcoal properties. Measurement of water content was carried out with three replications for each treatment. The relationship between the water content of coconut shell charcoal and experimental treatment is presented in Figure 2.

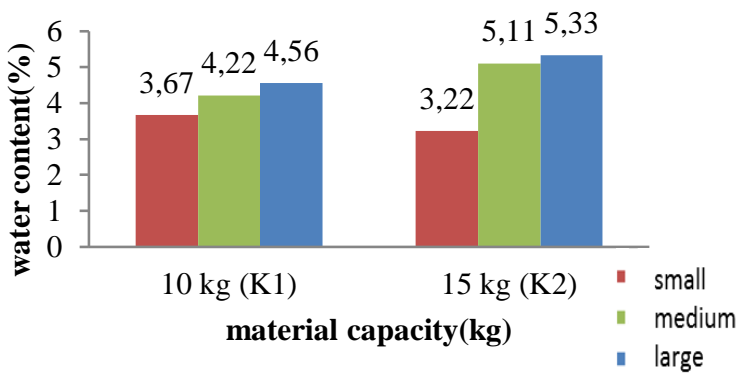

Figure 2. Graph of the effect of capacity on the water content of coconut shell charcoal.

The highest water content was obtained in the treatment with a large size, namely with a water content of $5.33 \%$, while for the lowest water content was in the treatment with a small size, namely with a water content of $3.22 \%$. The results showed that the water content of coconut shells in this study had met the quality requirements, which ranged from $3.22 \%-5.33 \%$ and slightly exceeded the maximum standard, so this shell charcoal had good quality. Figure 4 shows that the water content of coconut shells increases due to the large diameter of the shells. The value of water content will affect the quality of coconut shell charcoal that will be produced. According [11], the more water contained in coconut shell charcoal, the ignition of the charcoal will be difficult to turn on.

\section{b. Ash content}

Ash content plays an important role in making charcoal, the higher the ash content can reduce the calorific value of the briquettes produced. Ash is a non-combustible mineral left after the combustion process. Measuring the ash content is one of the parameters to determine the quality of the charcoal. The results of measuring the ash content of coconut shell charcoal can be seen in Figure 3.

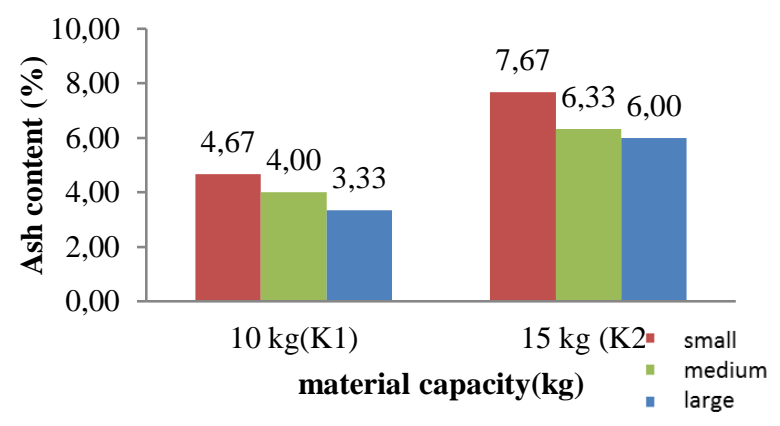

Figure 3. Graph of the effect of capacity on ash content of coconut shell charcoal

The graph shows that the value of ash content for a capacity of $10 \mathrm{~kg}$ is lower than that of $15 \mathrm{~kg}$, it shows that a capacity of $10 \mathrm{~kg}$ produces more charcoal than a capacity of $15 \mathrm{~kg}$. More the ash content contained in the charcoal, the less charcoal produced is compared to charcoal which has a low ash content. In this study, it was found that the ash content in the coconut shell charcoal treatment with a capacity of $10 \mathrm{~kg}$ had met the standards, which ranged from $3.33 \%-4.67 \%$, while in the treatment with a capacity of 15 $\mathrm{kg}$ did not meet the standard, the ash content in the treatment with a capacity of $15 \mathrm{~kg}$ which ranges from 6.00$7.67 \%$. Coconut shell charcoal with the lowest ash content was obtained in the treatment with a capacity of $10 \mathrm{~kg}$ with an ash content of $3.33 \%$ while for shell charcoal with the highest ash content was found in shell charcoal with a capacity of $15 \mathrm{~kg}$ with an ash content of $7.67 \%$.

\section{c. Volatile Substances (Volatile Matter)}

A volatile substance is a substance that can evaporate as a result of the decomposition of compounds that are still present in charcoal besides water, bonded carbon, and ash. The level of this flying substance will affect the amount of smoke produced and the ease with which the charcoal is ignited, the greater the level of flying matter, the easier the charcoal will ignite, but the smoke produced also increases [12]. The content of flying 
substances is a volatile compound content other than water in charcoal. The content of volatile matter in charcoal affects the parameters of the quality of the charcoal produced, the more volatile matter content in the bearing, the charcoal is easier to burn and ignite. The results of the measurement of volatile matter content are presented in Figure 4.

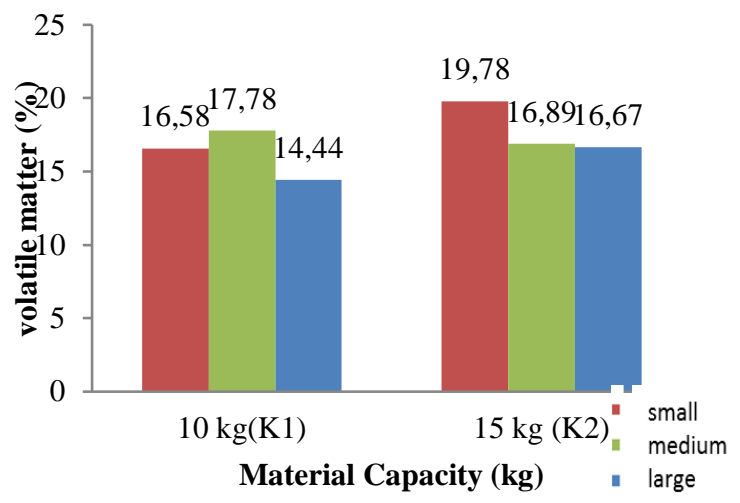

Figure 4. Graph of the effect of capacity on the volatile matter of coconut shell charcoal

The graph shows that the volatile levels in both treatments with a capacity of 10 and $15 \mathrm{~kg}$ have almost the same volatile values. At a capacity of $15 \mathrm{~kg}$, small size of $3-5 \mathrm{~cm}$ (K2L1) indicates a higher value of volatile matters, where a smaller shell size can make charcoal burning. The highest volatile matters were found in the treatment with a capacity of $15 \mathrm{~kg}$ with a small size of $3-5 \mathrm{~cm}$ with the value of a Volatile matter of $19.78 \%$, while for the lowest Volatile matters value was coconut shell charcoal in the treatment with a small capacity of $10 \mathrm{~kg}, 8-13 \mathrm{~cm}$, with the value of the Volatile matter of $14.44 \%$. The higher the value of the volatility of coconut shell charcoal, the more smoke will be produced during the combustion process. The results of the research show that the value of the Volatile matters for coconut shell charcoal has not met the standard, however, the treatment with a capacity of $10 \mathrm{~kg}$ with a large size shows the Volatile value matters which approximates the standard.

\section{d. Carbon Content (Fixed Carbon)}

Carbon content is one of the parameters that determine the quality of a briquette. The high carbon value will make the shell have a high heating value and have a longer burning time [13].

Fixed carbon is a residual solid fuel by reduced ash content, moisture content, and volatile matter. The value of fixed carbon is influenced by other charcoal content such as ash content, moisture content, and volatile matter. Charcoal can be said to be of quality or not determined from the carbon content in it. The higher the fixed carbon contained in the charcoal, the higher the quality of the charcoal because fixed carbon is the main generator of heat during combustion. The results of measuring the value of fixed carbon are presented in Figure 5 .

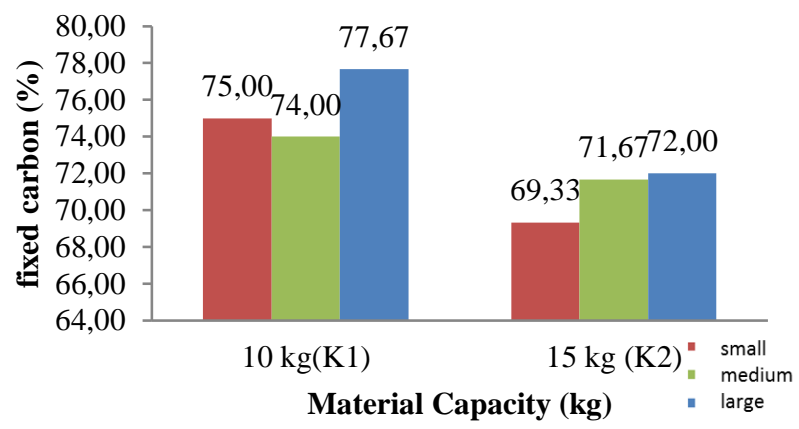

Figure 5. Graph of the effect of capacity on coconut shell charcoal fixed carbon

\subsection{Analysis of Cost of Production}

Industry or company must calculate the cost of goods because it is very important for industrial financial reporting. Details of the production costs for making charcoal and wood vinegar using kiln device can be seen in Table 3.

Based on Table 7. Values A, B, C can be calculated by formula analysis. From the above calculations, it can be seen that the value of $\mathrm{A}$ is 2,250,000.00 Rp / year, the value of $\mathrm{B}$ is $15,195,000.00 \mathrm{Rp}$ / year, the value of $\mathrm{C}$ for charcoal is $13,6 \%$, and wood vinegar is $3,6 \mathrm{ml} /$ hour and the number of hours worked in one year is 2,688 hours/year. It can be concluded from the calculation of the cost of production of charcoal and wood vinegar, namely the resulting selling price for charcoal and wood vinegar products was $10,000.00 \mathrm{Rp} / \mathrm{kg}$ and $30.000 .00 \mathrm{Rp} / 1000 \mathrm{ml}$. of the cost of production with the use of raw materials including coconut shell $10 \mathrm{~kg}$ for making charcoal and liquid smoke are Rp. 2.72 / g, and Rp. $5.65 / \mathrm{ml}$.

The price of charcoal and wood vinegar produced is very cheap when compared to the price in the local market, the point is that if the charcoal and wood vinegar business is run with kiln device (apropriate technology) it is very feasible to develop. 
Table 3. Details of production costs of charcoal and wood vinegar use kiln tools

\begin{tabular}{|c|c|c|c|c|}
\hline \multirow[t]{2}{*}{ No } & \multirow[t]{2}{*}{ Description } & \multicolumn{3}{|l|}{ Price $(\mathrm{Rp}$} \\
\hline & & Fixed Cost & Variabel Cost & Total (Rp) \\
\hline \multirow[t]{4}{*}{1} & Depreciation of Equipment: & & & \\
\hline & - Price of tools & Rp. 5.000.000,00 & & \\
\hline & - Rent (Year) & Rp. $500.000,00$ & & \\
\hline & Fixed cost $(\mathrm{A})$ & & & Rp. 5.500.000,00 \\
\hline \multirow[t]{6}{*}{2} & Material Cost: & & & \\
\hline & - Coconut shell $(1000 \mathrm{~kg})$ & & Rp. 8.400.000,00 & \\
\hline & - Indirect costs: & & 0 & \\
\hline & - Employee salary (1 Person/Year) & & Rp. 6.720.000,00 & \\
\hline & Equipment maintenance costs (1year) & & Rp. $75.000,00$ & \\
\hline & Variabel cost $(\mathrm{B})$ & & & Rp. 15.195.000,00 \\
\hline \multirow[t]{2}{*}{3} & The working hours per year & & & \\
\hline & 2688 hour/year & & & \\
\hline 4 & $\begin{array}{l}\text { Percentage }(\mathrm{C}) \\
\text { Charcoal is } 13,6 \% \text {, and wood vinegar is } 3,6 \%\end{array}$ & & & \\
\hline
\end{tabular}

\section{CONCLUSION}

The development of appropriate technology design is very simple and easy to use, namely the drumshaped kiln. The kiln design tool tested in this study showed the performance for charcoal burning with an average cooking temperature of $268^{\circ} \mathrm{C}$. The performance results using coconut shells showed a charcoal capacity of $10 \mathrm{~kg}$, indicating a high yield for charcoal capacity with shell materials in a drum-type kiln chamber. by using the same tools, but for wood vinegar with cooling condenser using a drum is quite good and capable of producing condensate. This kiln tool can operate as a charcoal maker or liquid smoke maker or both. In the making of charcoal (without the process of liquid smoke) obtained the optimal charcoal capacity at $10 \mathrm{~kg}$ of small size shell, the combustion temperature runs $150^{\circ} \mathrm{C}$ with a time of 2 hours and a yield of $24.5 \%$. Making liquid smoke (without making charcoal) shows the capacity of fumigation material (shell) using 20 $\mathrm{kg}$, the combustion temperature runs $120^{\circ} \mathrm{C}$ with a time of 6 hours and a yield of $5.5 \%$ or 1.1 liters. Whereas to get the combustion at the same time the liquid smoke obtained the results of the charcoal capacity to produce more than $10 \mathrm{~kg}$ of small size shell, the combustion temperature runs $120^{\circ} \mathrm{C}$ with 2.5 hours with the yield of charcoal and liquid smoke yield of $10.5 \%$ and $1.2 \%$. The results of the analysis of the cost of production with the use of raw materials including coconut shell $10 \mathrm{~kg}$ for making charcoal and liquid smoke are Rp. 2.72 / g, and Rp. 5.65 / ml.

Charcoal and wood vinegar product with kiln device (apropriate technology) it is very feasible to develop

\section{ACKNOWLEDGMENT}

This research was supported by the University of Bengkulu Research and
Community Service Institute with funding from the Director General of Higher Education

\section{REFERENCES}

[1] León-Ledesma M. A., and M Satchi. "Appropriate Technology and Balanced Growth. Review of Economic Studies 0, pp. 1-29, 2018. doi:10.1093/restud/rdy002

[2] Cantore, C., León-Ledesma, M. A., Mcadam, P.. "Shocking Stuff: Technology, Hours, and Factor Substitution", Journal of the European Economic Association, 12, pp. 108-128. 2014.

[3] Basu, S. and Weil, D. N. "Appropriate Technology and Growth", The Quarterly Journal of Economics, vol. 113, pp. 1025-1054, 1998.

[4] Antal M. J., Jr., E. Croiset, X. Dai, C. De Almeida, W. Shu-Lai Mok, and N. Norberg. "High-Yield Biomass Charcoal". Energy and Fuels, vol. 10, pp. 652-658, 1998.

[5] Antal M J, Jr., and M Grønli. "The Art, Science, and Technology of Charcoal Production". Ind. Eng. Chem. Res, vol. 42, pp. 1619-1640, 2003.

[6] Ratanapisit J., S. Apiraksakul, A. Rerngnarong,J. Chungsiriporn and C. Bunyakarn. "Preliminary evaluation of production and characterization ofwood vinegar from rubberwood". Songklanakarin J. Sci. Technol, vol. 31, no. 3, pp. 343-349, 2009.

[7] Nakai, T., Kartel, S. N., Hata, T. and Imamura, Y. "Chemical characterization of pyrolysis liquids ofwood-based composites and evaluation of their bio-efficiency“. Building and Environment. vol. 42, pp. 1236-1241, 2007. 
[8] Loo, A.Y., Jain, K. and Darah, I. “Antioxidant and radi-cal scavenging activities of the pyroligneous acidfrom a mangrove plant, Rhizophora apiculata“. Food Chemistry. vol. 107, pp. 300-307, 2007.

[9] Oramahi, H. A, T. Yoshimura, F. Diba, D. Setyawati, and Nurhaida. "Antifungal and antitermitic activities of wood vinegar from oil palm trunk". Journal of Wood Science, vol. 64, pp. 311-317, 2018. doi.org/10.1007/s10086-018-1703-2

[10] Tranggono S, Setiadji B, Darmadji P, Supranto S "Identifikasi Asap Cair dari Berbagai Jenis Kayu dan Tempurung Kelapa (in Indonesia)“. J Ilmu dan Teknologi Pangan, vol. 1, no. 2, pp. 15-24, (1996)
[11] Tirono M, and Sabit A. "Efek suhu pada proses pengarangan terhadap nilai kalor arang tempurung kelapa (in Indonesia) “. Jurnal Neutrino. vol. 3, pp. 84-86, 2011.

[12] Budiawan, L., B. Susilo., Y. Hendrawan. "Pembuatan dan Karakterisasi Briket Bioarang dengan Variasi Komposisi Kulit Kopi (in Indonesia)". Jurnal Bioproses Komoditas Tropis, vol. 2, no. 2, pp. 152 - 160. 2014.

[13] Basu, P. "Biomass Gasification and Phyrolisis: Practical Design”. Burlington (USA). Elseiver Inc. 2010. 